\title{
Effects of Salt Stress on Plant Growth, Nutrient Partitioning, Chlorophyll Content, Leaf Relative Water Content, Accumulation of Osmolytes and Antioxidant Compounds in Pepper (Capsicum annuum L.) Cultivars
}

\author{
Mathias J. HAND ${ }^{1}$, Victor D. TAFFOUO ${ }^{2 *}$, Alphonse E. NOUCK ${ }^{3}$, \\ Kitio P.J. NYEMENE ${ }^{2}$, Libert B. TONFACK ${ }^{1}$, \\ Tekam L. MEGUEKAM ${ }^{4}$, Emmanuel YOUMBI ${ }^{1}$ \\ ${ }^{1}$ University of Yaoundé I, Faculty of Science, Department of Biology and plant Physiology, Laboratory of Biotechnology and Environment, \\ Unit of Physiology and Plant Improvement P.O. Box 812 Yaounde, \\ Cameroon; Maty_hand@yahoo.fr; libricetonfack@yahoo.fr; youmbi_emmnuel@yahoo.fr \\ ${ }^{2}$ University of Douala, Faculty of Science, Department of Botany, P.O. Box 24157 Douala, \\ Cameroon;dtaffouo@univ-douala.com ('corresponding author);kitopaul@yahoo.fr; \\ ${ }^{3}$ University of Bamenda, Faculty of Sciences, Department of Biological Sciences, P.O. Box 39, Bamenda, Cameroon; alphonseervenouck@yahoo.fr \\ ${ }^{4}$ University of Yaounde I, Department of Biological Sciences, P.O. Box 47 Yaounde, Cameroon; fmeguekame@yahoo.fr
}

\begin{abstract}
The salinity of soil is among the most important abiotic stresses which limit agricultural productivity worldwide. The effects of salinity on growth, nutrient partitioning, chlorophyll, leaf relative water content, osmolytes accumulation and antioxidant compounds of pepper (Capsicum annum L.) cultivars ('Granada', 'Goliath' and 'Nobili'), widely used in Cameroon, were investigated. Plants were subjected to four levels of $\mathrm{NaCl}(0,50,100$ and $200 \mathrm{mM}$ ) at early seedling growth stage of plant development. Application of $\mathrm{NaCl}$ treatment led to a significant increase in total soluble sugars, proline, soluble proteins, total free amino acids content, peroxydase and superoxide dismutase activity and total phenolic content in salt-tolerant 'Granada' and 'Nobili' compared to salt-sensitive 'Goliath' and untreated plants, on the contrary, decreased in root dry weight, shoot dry weight, number of leaves, shoot length, stem diameter, total leaf area, chlorophyll and leaf relative water content in 'Goliath' at low salinity level. Flavonoid content, $\mathrm{K}, \mathrm{Ca}$ and $\mathrm{Mg}$ concentrations were significantly reduced with increasing salinity in all cultivars. The highest $\mathrm{Na}$ concentrations were detected in the leaves while the lowest were recorded in the roots of 'Goliath' at high salinity level. The salt sensitivity of 'Goliath' seems to be increased osmotic adjustment through the strongly accumulation of $\mathrm{Na}$ in leaves while the salt tolerance of 'Granada' was related to its induce of antioxidative enzyme system more efficiently, resulting in higher osmolytes accumulation under salinity. 'Granada' was more tolerant and stable in physiological and biochemical traits suggesting that it could be grown in salt-affected soils.
\end{abstract}

Keywords: antioxidative defense system, compatible solutes, ions distribution, pepper, plant growth, salinity Abbreviations: Calcium-Ca; chlorophyll-CHL; days after planting-DAP; flavonoids-FLA; magnesium-Mg; number of leavesNL; peroxydase-POD; phosphorus-P; potassium-K; proline-PRO; relative water content-RWC; root dry weight-RDW; shoot dry weight-SDW; shoot length-SL; soluble proteins-SP; stem diameter-SD; superoxide dismutase-SOD; total free amino acids content-FAA; total leaf area-TLA; total phenolic-TP; total plant dry weight-PDW; total soluble sugars-SS.

\section{Introduction}

Salinity is a major environmental factor determining plant productivity in most arid and semi-arid areas of the world. It affects more than $10 \%$ of arable land and salinization is rapidly increasing on a global scale, declining average yield for most major crop plants by more than $50 \%$ (Bray et al., 2000). Salt stress occurs in areas where soils are naturally over salted and precipitation is low and/or where irrigation, hydraulic lifting of salty underground water, or invasion of sea water in coastal areas brings salt to the surface soil that inhabit plants (Neumann, 1995). Globally 
482

$20 \%$ of irrigated land and $2.1 \%$ of dry land agriculture suffers from the salt problem and $\mathrm{NaCl}$ is the predominant salt causing salinization (Munns and Tester, 2008). Salinity adversely affects germination, growth, physiology and productivity by reducing the ability of plants to take up water causing foliage damage and even death of the plants, imbalance in osmotic potential; ionic equilibrium and nutrient uptake (Niu et al., 1995). Further, it facilitates severe ion toxicity by depositing high concentration of $\mathrm{Na}^{+}$ which causes membrane disorganization, inhibition of cell division and expansion. The influence of salinity and mineral nutrient solution, on productivity, photosynthesis and growth has been studies in different plants (Hosseini and Thengane, 2007; Li et al., 2008; Taffouo et al., 2010). It stated that high levels of $\mathrm{Na}^{+}$inhibits $\mathrm{K}, \mathrm{Ca}$ and $\mathrm{Mg}$ in leaves, which results in a $\mathrm{K} / \mathrm{Na}$ antagonism and net photosynthesis is affected strongly by $\mathrm{NaCl}$ conditions, which is related directly to the closure of stomata as to low intercellular $\mathrm{CO}_{2}$ levels (Al-Karaki, 2000; Turan et al., 2007). To develop saline zones and/or the zones having only brackish water resources, it is important to select tolerant varieties. Salinity imposes stress conditions on crop plants and affects growth and chemical contents and has been shown to limit pepper yield (Paridam and Das, 2005). Salt stress severely inhibits plant growth for two reasons: firstly due to an osmotic or water-deficit effect of salinity and secondly due to a salt-specific or ion excess effect of $\mathrm{NaCl}$. Moreover, plants subject to salinity stress conditions produce cytotoxic activated oxygen that can seriously disrupt normal metabolism, through oxidative damage of lipids, proteins, and nucleic acids (Abbaspour, 2012). To defend against such oxidants, plants have evolved specific protective mechanisms, involving antioxidant molecules and enzymes that protect against the potentially-cytotoxic species of activated oxygen.

The responses of plants to high soil salinity and the mechanisms of salt tolerance have been discussed in many works published (Grigore et al., 2011; Meguekam et al., 2014; Nouck et al., 2016). Such salt tolerance mechanisms include ion homeostasis system via salt glands/salt bladders, osmoregulation system such as free proline, glycine betaine, mannitol and soluble sugars, hormonal regulation, and antioxidant machinery (Hasegawa et al., 2000; Flowers and Colmer, 2008). Compartmentation of ions in vacuoles and accumulation of compatible solutes in the cytoplasm are commonly proposing mechanisms to salt tolerance of plants (Munns, 2002). In salt tolerant species, the osmotic balance of the cytoplasm is ensured by an active synthesis of the organic and soluble compounds (Grigore et al., 2011). In plants, SP are involved in osmotic adjustment. They are stored as nitrogen under salt-stress and re-used when the stress is removed (Singh et al., 1987). When different abiotic stresses affect plant functionality, alterations in photosynthesis and carbon partitioning are common features that take place at organ level as well as in whole plant (Gill et al., 2003). SS do not only function as metabolic resources and structural constituents of cells, they also act as signals regulating various processes associated with plant growth and development (Jang and Sheen, 1997). Recent studies for increasing tolerance to environmental stresses, through metabolic engineering of compatible solutes, have shown that increases in SS and/or other osmolytes provide optimism to increase plant tolerance to abiotic stresses such as drought, salinity and cold (Cusido et al., 1987; Rathinasabapathi, 2000). PRO is probably the most common compatible solutes synthesized by plants as a response to abiotic stress (Ashraf and Foolad, 2007; Meguekam et al., 2014). PRO is significantly accumulated under salt stress and performs the positive role in the adaptation of cells to salt and water stress (Kaviani, 2008). Deficit of K induced by salinity increased the levels of FAA, especially of aspartic acid, glutamic acid and PRO (Cusido et al., 1987).

The salt-induced disturbance in ionic homeostasis causes a cascade of secondary effects such as oxidative stress due to reactive oxygen species (ROS) production (Ashraf, 2009; Joseph and Jini, 2011). In response to stress, plants activate powerful antioxidant systems, both enzymatic (e.g., superoxide dismutase, catalase, glutathione reductase, peroxidase) and non-enzymatic (vitamins $\mathrm{C}$ and $\mathrm{E}$, carotenoids, flavonoids and other phenolic compounds) (Azooz et al., 2009). SOD and catalase are known as the most effective enzymes in scavenging of active oxygen species which cause oxidative stress (Karanlik, 2001). However, an active antioxidative defense system comprising enzymatic and non-enzymatic antioxidants reduces the level of oxidative stress in plant cells by scavenging free radicals (Azooz et al., 2009; Abogadallah et al., 2010). In case of high salinity, oxidative stress occurs due to closure of stomata, interruption of photosynthetic electron transport and disruption of cellular membrane integrity and antioxidative defense systems of plants start work against oxidative damage. SOD is metalloenzyme that catalyze the dismutation of the superoxide anion to molecular oxygen and hydrogen peroxide and thus form a crucial part of the cellular antioxidant defense mechanism (Malstrom et al., 1975). Numerous studies have reported that salinity treatment increased POD activity in plants (Jebara et al., 2005; Mohamed and Aly, 2008; Chookhampaeng, 2011; Sevengor et al., 2011). FLA has been recently suggested as playing primary antioxidant functions in the responses of plants to a wide range of abiotic stresses (Brunetti $e t$ al., 2013). They act in plants as antioxidants, antimicrobials, photoreceptors, visual attractors, feeding repellants, and for light screening (Pietta, 2000). FLA is formed in plants from the aromatic amino acids phenylalanine and tyrosine, and malonate (Cody et al., 1986). However, most interest has been devoted to the antioxidant activity of FLA, which is due to their ability to reduce free radical formation and to scavenge free radicals (Pietta, 2000). FLA in the vacuole of mesophyl cells are in very high concentrations and hence capable of removing $\mathrm{H}_{2} \mathrm{O}_{2}$ freely diffusing out of the chloroplast under severe excess light stress, when the activity of catalase is strongly depressed (Polle, 2001). Flavonoid glycosides have a much smaller affinity than corresponding aglycones for peroxidases, but their concentrations may allow detoxify $\mathrm{H}_{2} \mathrm{O}_{2}$ efficiently (Agati et al., 2012). The reducing functions of FLA are of primary significance in plants suffering from severe stress conditions (Brunetti et al., 2013). FLA compounds are a large group of secondary metabolites, which can play a role in virtually any interaction a plant can have with its environment 
(Waterman and Mole, 1994). These compounds have been implicated to stress resistance against biotic and abiotic factors (Bergmann et al., 1994). TP compounds are a large group of secondary metabolites, which can play a role in virtually any interaction a plant can have with its environment (Waterman and Mole, 1994). These compounds have been implicated to stress resistance against biotic and abiotic factors (Bergmann et al., 1994; Meguekam et al., 2014). TP accumulation could be a cellular adaptive mechanism for scavenging oxygen free radicals during stress (Mohamed and Aly, 2008).

Pepper (Capsicum annuum L.) is an important agricultural crop, because of its economic importance and the nutritional value of its fruits; it is an excellent source of natural colors, vitamin $\mathrm{C}$ and antioxidant compounds worthy for human health (Howard et al., 2000). Screening plant species for salinity tolerance or genetic potential to develop tolerance are promising approaches for developing salt tolerant commercial cultivars (Munns and Tester, 2008). The aim of the present work was to study the comparative effects of different concentrations of $\mathrm{NaCl}$ on growth, nutrient partitioning, osmolytes accumulation, total chlorophyll, relative water content and antioxidant compounds in pepper cultivars. Comparison of these parameters in these pepper cultivars may be helpful to provide additional information on the mechanisms of salt tolerance and develop salt tolerant cultivars for breeding program.

\section{Materials and Methods}

\section{Plantmaterials}

Pepper (Capsicum annuum L.) is especially productive in warm and dry climates than $C$. frutescens which can tolerate most climates. It also displays a greater resistance to disease and insects, especially to the tobacco mosaic virus. Capsaicinoids chemicals and antioxidants such as carotenoids provide the distinctive tastes in C. annuun variants. The fruit are berries that may be green, yellow or red when ripe. The mature green stage is ideal to acquire maximum pungency due to capsaicinoids, whereas peppers at red ripe stage are best sources of ascorbic acid and dried fruits contain higher levels of total carotenoids (Iqbal et al., 2013). Hot peppers are used in medicine as well as food in Africa. Seeds of three pepper cultivars ('Granada', 'Goliath' and 'Nobili'), provided by the breeding program of the Agronomic Institute for Research and Development of Cameroon were used in the study.

\section{Plantgrowth conditions and salt treatments}

The present work was performed in the greenhouse of the Faculty of Science at University of Douala, Cameroon, from October 2013 to May 2014. The seeds were surface sterilized with 3\% sodium hypochlorite for $20 \mathrm{~min}$ and washed four times with deionized water. One-month-old pepper seedlings were transplanted into $5-\mathrm{L}$ plastic pots filled with $5 \mathrm{~kg}$ of sterilized sand. The pots were arranged in a complete randomized design with one plant per pot and four replicates per treatment. All plants were fertilized daily with a modified

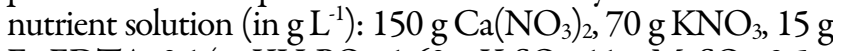
Fe-EDTA, $0.14 \mathrm{~g} \mathrm{KH}_{2} \mathrm{PO}_{4}, 1.60 \mathrm{~g} \mathrm{~K}_{2} \mathrm{SO}_{4}, 11 \mathrm{~g} \mathrm{MgSO}_{4}, 2.5 \mathrm{~g}$ $\mathrm{CaSO}_{4}, 1.18 \mathrm{~g} \mathrm{MnSO}_{4}, 0.16 \mathrm{~g} \mathrm{ZnSO}_{4}, 3.10 \mathrm{~g} \mathrm{H}_{3} \mathrm{BO}_{4}, 0.17 \mathrm{~g}$
$\mathrm{CuSO}_{4}$ and $0.08 \mathrm{~g} \mathrm{MoO}_{3}$ (Hoagland and Arnon, 1950). The $\mathrm{pH}$ of the nutrient solution was adjusted to 7.0 by adding $\mathrm{HNO}_{3} 0.1 \mathrm{mM}$. For the determination of physiological and biochemical responses of pepper cultivars to salt stress, each cultivar was subjected to 0 (control), 50, 100 and $200 \mathrm{mM}$ $\mathrm{NaCl}$. Plants were watered with deionized water every morning. The daily amounts of water added to the pots were the same for all treatments. Throughout the growth period, average day/night temperatures in the greenhouse were 26 ${ }^{\circ} \mathrm{C} / 20^{\circ} \mathrm{C}$ and the relative air humidity averaged $68.5 \%$.

\section{Plant growth parameters}

Plants were harvested 42 DAP. SL, SD, NL and TLA were recorded. Leaves, stems, and roots were separately dried at $70{ }^{\circ} \mathrm{C}$ for $72 \mathrm{~h}$, and their dry weights were determined. The RWC ((leaf FW-leaf DW) ${ }^{*} 100 /$ leaf FW) and TLA (length* width ${ }^{*} 0.80^{*}$ total no. of leaves ${ }^{*} 0.662$ ) were calculated using the methodology described by Kumar et al. (2002). Leaf CHL content was determined using Arnon (1949) method. Subsamples $(20 \mathrm{mg}$ ) of fresh leaves were extracted with $80 \%$ alkaline acetone (v/v). The filtrate was analyzed with a spectrophotometer (BECKMAN DU-68, UV/VIS) at 645 and $663 \mathrm{~nm}$ wavelengths.

\section{Nutrient contents}

For determination of $\mathrm{K}, \mathrm{Na}, \mathrm{Ca}$, and $\mathrm{Mg}$, subsamples (300 $\mathrm{mg}$ ) of dried ground leaves (including leaves lost over the growth period) were dry ashed at $550{ }^{\circ} \mathrm{C}$ for $4 \mathrm{~h}$ and thoroughly mixed with $250 \mathrm{~mL}$ of deionized water. The filtrate was analyzed with an atomic absorption spectrophotometer (EPOS 5060, Eppendorf, Hamburg, Germany).

\section{Osmolyte contents}

For measurement of SS content, a modified phenolsulfuric assay was used (Dubois et al., 1956). Subsamples (100 $\mathrm{mg}$ ) of dry leaves were placed in $50 \mathrm{~mL}$ centrifuge tubes. $20 \mathrm{~mL}$ of extracting solution (glacial acetic acid:methanol:water, 1:4:15 (v/v/v)) was added to the ground tissue and homogenized for $15 \mathrm{sec}$ at $16000 \mathrm{rpm}$. The homogenate was centrifuged for $10 \mathrm{mn}$ and the supernatant was decanted to a $125 \mathrm{ml}$ Erlenmeyer flask. The residue was resuspended in 20 $\mathrm{mL}$ of extracting solution and centrifuged another $5 \mathrm{~min}$. The supernatant was decanted, combined with the original extract, and made up to $100 \mathrm{~mL}$ with water. One $\mathrm{mL}$ of $5 \%(\mathrm{v} / \mathrm{v})$ phenol solution and $5 \mathrm{~mL}$ of concentrated $\mathrm{H}_{2} \mathrm{SO}_{4}$ were added to $1 \mathrm{~mL}$ aliquots of SS (reconstituted with $1 \mathrm{~mL}$ water). The mixture was shaken, cooled to room temperature, and absorbance recorded at $490 \mathrm{~nm}$ wavelength with spectrophotometer (Pharmaspec UV-1700 model). The amount of SS present in the extract was calculated using standard curve prepared from graded concentration of glucose.

Pro content was estimated by acid ninhydrin procedure (Bates et al., 1973). Subsamples ( $0.5 \mathrm{~g})$ of fresh leaves were homogenized in $10 \mathrm{~mL}$ of $3 \%(\mathrm{~W} / \mathrm{v})$ aqueous sulfosalicylic acid to precipitate protein. The reaction mixture consisted of 1 $\mathrm{ml}$ acid ninhydrin and $1 \mathrm{ml}$ of glacial acetic acid, which was boiled at $100^{\circ} \mathrm{C}$ for $1 \mathrm{~h}$. After cooling of the tubes in ice, the products were extracted with $2 \mathrm{ml}$ of toluene by vortex mixing and the upper (toluene) phase decanted into a glass basin. The absorbance was read with a spectrophotometer (Pharmaspec UV-1700 model) at $520 \mathrm{~nm}$ wavelength. 
484

PR content was evaluated using the Bradford (1976) method. Subsamples $(0.1 \mathrm{~g})$ of fresh leaves were homogenized with $4 \mathrm{~mL}$ of sodium-phosphate buffer, $\mathrm{pH}$ 7.2. The mixture was then centrifuged at $13000 \mathrm{rpm}$ for $4.5 \mathrm{~min}$ at $4^{\circ} \mathrm{C}$. One milliliter of the supernatant was poured into a tube containing $5 \mathrm{~mL}$ of the Bradford reagent. The mixture was then shaken and incubated in the dark for $15 \mathrm{~min}$. The absorbance of the resulting blue complex was read at $595 \mathrm{~nm}$ wavelength with a spectrophotometer (Pharmaspec UV-1700 model). The standard curve was obtained using Bovine Serum Albumin 1 $\mathrm{mg} \mathrm{mL}^{-1}$.

FAA content was determined by the ninhydrin method (Yemm et al., 1955). Subsamples (1 g) of fresh leaves were ground in $5 \mathrm{~mL}$ of ethanol $80 \%$, amino acids were then extracted using reflux technique in boiling ethanol for $30 \mathrm{~min}$. The filtrate was collected and the residue used to repeat the extraction. The two mixed filtrates constituted the raw extract of amino acids that were measured using ninhydrin method. The absorbance of purplish bruise complex was read at $570 \mathrm{~nm}$ wavelength. The standard curve was established using $0.1 \mathrm{mg}$ $\mathrm{mL}^{-1}$ of glycine.

\section{Antioxidant and non-enzymatic antioxidants}

POD activity was determined according to the method described by Jebara et al. (2005). The assay mixture of $3 \mathrm{ml}$ contained $1.5 \mathrm{ml}$ of $0.1 \mathrm{M}$ phosphate buffer $(\mathrm{pH} 7.0), 1 \mathrm{ml}$ freshly prepared $10 \mathrm{mM}$ guaiacol, $0.1 \mathrm{ml}$ enzyme extract and $0.1 \mathrm{ml}$ of $12.3 \mathrm{mM} \mathrm{H}_{2} \mathrm{O}_{2}$. Initial absorbance was read at 436 $\mathrm{nm}$ wavelength and then increase in the absorbance was noted at the interval of $30 \mathrm{~s}$ on spectrophotometer (Pharmaspec UV1700 model). Activity was calculated using the extinction coefficient $26.6 \mathrm{mM}^{-1} \mathrm{~cm}^{-1}$ for the oxidized tetraguaiacol polymer. Enzyme activity was expressed as $\mu \mathrm{mol}$ guaiacol oxidized $\min ^{-1} \mathrm{~g}^{-1}$ protein.

SOD activity was determined according to the method described by Dhindsa et al. (1981). Three $\mathrm{mL}$ of reaction mixture containing $0.1 \mathrm{~mL}$ of $1.5 \mathrm{M} \mathrm{Na}_{2} \mathrm{CO}_{3}, 0.2 \mathrm{~mL}$ of 200 $\mathrm{mM}$ methionine, $0.1 \mathrm{~mL}$ of $3 \mathrm{mM}$ EDTA, $0.1 \mathrm{~mL}$ of $2.25 \mathrm{mM}$ $p$-nitroblue tetrazolium chloride (NBT), $1.5 \mathrm{~mL}$ of $100 \mathrm{mM}$ potassium phosphate buffer ( $\mathrm{pH} 7.5), 1 \mathrm{~mL}$ of distilled water and $0.05 \mathrm{~mL}$ of enzyme samples. The tube without enzyme was taken as control. Reaction was started by adding $0.1 \mathrm{ml} 60$ $\mu \mathrm{M}$ riboflavin and placing the tubes below a light source of two $15 \mathrm{~W}$ fluorescent lamps for $15 \mathrm{~min}$. The reaction was stopped by switching off the light and covering the tubes with black cloth. Absorbance was recorded at $560 \mathrm{~nm}$ wavelength. An illuminated blank without protein gave the maximum reduction of NBT, and therefore, the maximum absorbance at $560 \mathrm{~nm}$ wavelength. SOD activity is presented as absorbance of blank minus absorbance of sample, giving the total inhibition, calculated per microgram protein. The activity of SOD was expressed as $\mathrm{U} \mathrm{mg}^{-1}$ protein.

TP content of the extract was determined by the FolinCiocalteu method (Marigo, 1973). Subsamples (1 g) of fresh leaves were ground at $4{ }^{\circ} \mathrm{C}$ in $3 \mathrm{~mL}$ of $0.1 \mathrm{~N} \mathrm{HCl}$. After incubation to $4{ }^{\circ} \mathrm{C}$ during $20 \mathrm{~min}$, the homogenate was centrifuged at $6000 \mathrm{~g}$ during $40 \mathrm{~min}$. The supernatant was collected, the pellet re-suspended in $3 \mathrm{~mL}$ of $0.1 \mathrm{~N} \mathrm{HCl}$ and centrifuged as previously. The two supernatant are mixed and constitute the crude extract of soluble phenol. The reaction mixture containing $15 \mu \mathrm{L}$ of extract, $100 \mu \mathrm{L}$ Folin-Ciocalteu reagents, $0.5 \mathrm{~mL}$ of $20 \% \mathrm{Na}_{2} \mathrm{CO}_{3}$ was incubated at $40{ }^{\circ} \mathrm{C}$ for 20 min and absorbance read at $720 \mathrm{~nm}$ wavelength with a spectrophotometer (Pharmaspec UV-1700 model). A standard curve was established using chlorogenic acid. TP content was expressed as $\mathrm{mgg}^{-1}$ fresh weight.

FLA content of crude extract was determined by the aluminium chloride colorimetric method (Chang et al., 2002). $50 \mu \mathrm{L}$ of crude extract $(1 \mathrm{mg} / \mathrm{mL}$ ethanol) were made up to 1 $\mathrm{mL}$ with methanol, mixed with $4 \mathrm{~mL}$ of distilled water and then $0.3 \mathrm{~mL}$ of $5 \% \mathrm{NaNO}_{2}$ solution; $0.3 \mathrm{~mL}$ of $10 \% \mathrm{AlCl}_{3}$ solution was added after $5 \mathrm{~min}$ of incubation, and the mixture was allowed to stand for $6 \mathrm{~min}$. Then, $2 \mathrm{~mL}$ of $1 \mathrm{~mol} / \mathrm{L} \mathrm{NaOH}$ solution were added, and the final volume of the mixture was brought to $10 \mathrm{~mL}$ with double-distilled water. The mixture was allowed to stand for $15 \mathrm{~min}$, and absorbance was recorded on spectrophotometer (Pharmaspec UV-1700 model) at 510 $\mathrm{nm}$ wavelength. FLA content was calculated from a rutin calibration curve, and the result was expressed as g rutin equivalent per g dry weight.

\section{Experimental design and statistical analysis}

The experiment was conducted as a factorial completely randomized design with four $\mathrm{NaCl}$ treatments and three cultivars in five replications. Data are presented in term of mean ( \pm standard deviation). All data were statistically analysed using Statistica (version 9, Tulsa, OK, USA) and first subjected to analyses of variance (ANOVA). Statistical differences between treatment means were established using the Fisher LSD test at $\mathrm{p}<0.05$.

\section{Results and Discussion}

\section{Plant growth}

Pepper growth was estimated by measuring RDW, SDW, SL, SD, NL and TLA of three cultivars plants under four $\mathrm{NaCl}$ concentrations at vegetative stage (42 DAP). There were statistically significant differences among the cultivars for all salt concentrations and plant growth parameters. Application of $\mathrm{NaCl}$ treatment led to a significant decrease in RDW, SDW, SL, SD, NL and NR of 'Goliath' compared to untreated plants (Table 1). The main effect of $\mathrm{NaCl}$ on plant growth parameters was that plants of 'Granada' and 'Nobili' under 50 $\mathrm{mM} \mathrm{NaCl}$ remained almost unaffected for SDW, SL, NL and TLA and presented significantly increased values for RDW and SD as compared to those of untreated plants while the main effect of the cultivar on the majority of growth parameters determined was that 'Goliath' was negatively affected by $\mathrm{NaCl}$ treatment and presented significantly lower values compared to 'Granada' whereas 'Nobili' showed intermediate ones. The effect of salt on plant growth inhibition was notably noted at $100 \mathrm{mM} \mathrm{NaCl}$ in 'Granada' and 'Nobili' for SDW, SL and TLA but 'Granada' had higher values than 'Nobili' (Table 1). The interaction cultivar $\mathrm{x}$ salt treatment was significant for SDW and SL (Table 1). The reduction of growth parameters in salt sensitive 'Goliath' is a consequence of several physiological responses including modification of ion balance, mineral nutrition, stomatal behaviour and photosynthetic efficiency (Hosseini and Thengane, 2007; Li et al., 2008; Mudgal et al., 2010). This is consistent with the reports that $\mathrm{NaCl}$ reduces the ability of the plant to take up water, and this leads to slow growth; then when excessive amounts of salt entering the transpiration stream will eventually injure cells in the transpiring leave and this may further reduce growth (Munns, 2002). In the present study, 
the salt inhibition effect in growth parameters studied was significantly noted at $50 \mathrm{mM} \mathrm{NaCl}$ in 'Goliath', while 'Granada' and 'Nobili' were significantly $(\mathrm{p}<0.05)$ affected at $100 \mathrm{mM} \mathrm{NaCl}$. These results demonstrate that 'Goliath', in common with certain other leguminous plant (e.g. beans), is highly sensitive to salt with severe effects at $50 \mathrm{mM} \mathrm{NaCl}$ (Levitt, 1980; Taffouo et al., 2009). Under salt stress 'Granada' was observed to have relatively higher tolerance on average of all growth parameters than 'Nobili', intermediate ones. Similar observations for plant growth were reported in 'White seed coat' (Taffouo et al., 2010) and 'Fleur 11' (Meguekam et al., 2014), described as salt-tolerant cultivars. In the first phase of a biphasic model of growth response to salinity, the vegetative growth is reduced by a decrease in a soil water potential due to water stress effect and may be regulated by inhibitory signals from the roots (Munns, 2002). The fact that salt stress resulted in a considerable decrease of SDW and RDW has been mentioned by other researchers (Nagesh Babu and Devaraj, 2008; Meguekam et al., 2014). However, salinity affected root growth less than shoot growth in 'Granada' and 'Nobili' in the present work. These results corroborate the findings of Cordovilla et al. (1999) with Vicia faba plants but they contradict those of Wignarajah (1992) and Bayuelo-Jiménez et al. (2002) with Phaseolus vulgaris.

\section{Nutrient uptake}

The main effect of $\mathrm{NaCl}$ on leaf, stem and root $\mathrm{Na}$ concentrations of plants under salt stress showed significant increases as compared to control plants (Table 2). The highest $\mathrm{Na}$ concentrations $\left(14.60 \mathrm{~g} \mathrm{~kg}^{-1}\right)$ were detected in the leaves while the lowest $\left(9.70 \mathrm{~g} \mathrm{~kg}^{-1}\right)$ were recorded in the roots of 'Goliath' at $200 \mathrm{mM} \mathrm{NaCl}$ (Table 2). These results are in accordance with those of Slama (1986) who found that the salt sensitivity of some crops was related to its higher concentration of $\mathrm{Na}$ in the leaves and lower in the roots but they contradict those of Taffouo et al. (2010) who found that the retention of $\mathrm{Na}^{+}$in the roots allows the salt sensitive 'Red Seed Coat' landrace to avoid the invasion of the leaves by toxic elements that are likely to reduce the photosynthetic activity by interfering with the opening of stomata and other metabolic processes (Turan, 2007). Na concentrations in the leaf tissues increased significantly under salt treatment in salt-tolerant 'Granada' and 'Nobili' (Table 2). $\mathrm{Na}^{+} / \mathrm{H}^{+}$exchanger (NHXs) in halophytic species has been well established as a major channel to manage the $\mathrm{Na}$ influx from the soil solution into root cell and translocate via xylem loading to other organs, leading to increased $\mathrm{Na} / \mathrm{K}$ ratio (Flowers and Colmer, 2008; $\mathrm{Li}$ et al., 2008). Similar observations were reported by Taffouo et al. (2004) and Theerawitaya et al. (2015) with two halophyte legumes (Phaseolus adenanthus and Acacia ampliceps). In this study, K, Ca and Mg concentrations were significantly reduced with increasing salinity in all cultivars (Table 2). It has been reported that salinity affects plant physiology through changes of water and ionic status in the cells because of ionic imbalance due to excessive accumulation of $\mathrm{Na}$ and $\mathrm{Cl}$ and reduced uptake of other mineral nutrients, such as $\mathrm{K}, \mathrm{Ca}$ and $\mathrm{Mg}$ (Hasegawa et al., 2000). According to Saghir et al. (2002), the ionic stress affects plant growth by increasing $\mathrm{Na}$ and $\mathrm{Cl}$ levels in cells in response to high concentrations of $\mathrm{NaCl}$, and decreased $\mathrm{Ca}, \mathrm{K}$, and $\mathrm{Mg}$ concentrations. This could be also attributed to the competition of $\mathrm{Na}$ with the uptake $\mathrm{K}$, resulting in a $\mathrm{K} / \mathrm{Na}$ antagonism (Hosseini and Thengane, 2007). The leaf $\mathrm{K} / \mathrm{Na}$ ratios were found to be significantly highest in 'Granada' and lowest in 'Goliath' (Table 2). The relationship between the degree to which plant tolerate salt stress and their capacity to maintain a high leaf ratio $\mathrm{K} / \mathrm{Na}$ has been noted by several authors (Al-Karaki, 2000).

\section{Chlorophyll concentrations}

In the present study, the depressive effect of salt was less marked on leaf CHL content in 'Granada' compared to 'Nobili', 'Goliath' and untreated plants (Fig. 1). $\mathrm{NaCl}$ treatment decreased the leaf CHL content in the salt sensitive 'Goliath' at low concentration $(50 \mathrm{mM})$. This effect of salt was attributed to salt-induced weakening of protein-pigment-lipid complex (Strogonov, 1970) or increased chlorophyllase

Table 1. Effect of salt stress on plant growth in pepper cultivars at the vegetative stage (42 DAP)

\begin{tabular}{|c|c|c|c|c|c|c|c|}
\hline \multirow{2}{*}{ Cultivar } & \multirow{2}{*}{$\begin{array}{c}\text { Treatment } \\
(\mathrm{mM} \mathrm{NaCl})\end{array}$} & \multicolumn{2}{|c|}{ PDW $\left(\right.$ g plant $\left.^{-1}\right)$} & \multirow{2}{*}{$\begin{array}{l}\mathrm{SD} \\
(\mathrm{cm})\end{array}$} & \multirow{2}{*}{$\begin{array}{c}\text { SL } \\
(\mathrm{cm})\end{array}$} & \multirow{2}{*}{ NL } & \multirow{2}{*}{$\begin{array}{c}\text { TLA } \\
\left(\mathrm{cm}^{2} \text { plant }^{-1}\right)\end{array}$} \\
\hline & & RDW & SDW & & & & \\
\hline \multirow{4}{*}{ Granada } & 0 & $0.17 \pm 0.08 \mathrm{e}$ & $3.33 \pm 0.16 \mathrm{a}$ & $1.85 \pm 0.19^{\mathrm{e}}$ & $9.90 \pm 0.53 \mathrm{~d}$ & $9.00 \pm 0.50 \mathrm{a}$ & $44.23 \pm 2.60 \mathrm{a}$ \\
\hline & 50 & $0.11 \pm 0.01 \mathrm{f}$ & $3.30 \pm 0.18 \mathrm{a}$ & $2.00 \pm 0.04 \mathrm{c}$ & $9.80 \pm 0.21 \mathrm{~d}$ & $8.85 \pm 0.50 \mathrm{a}$ & $40.51 \pm 1.20 \mathrm{a}$ \\
\hline & 100 & $0.92 \pm 0.13 \mathrm{a}$ & $3.18 \pm 0.15 b$ & $2.10 \pm 0.01 \mathrm{~b}$ & $8.60 \pm 0.10 \mathrm{f}$ & $7.75 \pm 0.52 d$ & $30.50 \pm 2.09 c$ \\
\hline & 200 & $0.77 \pm 0.10 \mathrm{c}$ & $3.10 \pm 0.13 c$ & $2.10 \pm 0.14 \mathrm{~b}$ & $6.10 \pm 0.14 j$ & $6.75 \pm 0.50 \mathrm{f}$ & $20.28 \pm 1.60 \mathrm{~d}$ \\
\hline \multirow[t]{4}{*}{ Goliath } & 0 & $0.75 \pm 0.02 f$ & $3.10 \pm 0.13 c$ & $2.10 \pm 0.11 b$ & $11.85 \pm 0.11 \mathrm{a}$ & $8.50 \pm 0.40 \mathrm{~b}$ & $28.76 \pm 1.42 \mathrm{c}$ \\
\hline & 50 & $0.51 \pm 0.07 \mathrm{f}$ & $2.81 \pm 0.20 \mathrm{~d}$ & $1.98 \pm 0.09 \mathrm{c}$ & $7.75 \pm 0.81 \mathrm{~g}$ & $7.25 \pm 0.51 \mathrm{e}$ & $23.74 \pm 1.40 \mathrm{~d}$ \\
\hline & 100 & $0.45 \pm 0.11 \mathrm{c}$ & $1.53 \pm 0.09 \mathrm{e}$ & $1.95 \pm 0.10 \mathrm{c}$ & $7.38 \pm 0.50 \mathrm{~h}$ & $6.50 \pm 0.57 \mathrm{~g}$ & $22.31 \pm 1.38 \mathrm{~d}$ \\
\hline & 200 & $0.34 \pm 0.03 \mathrm{~d}$ & $0.99 \pm 0.03 \mathrm{f}$ & $2.15 \pm 0.18 \mathrm{a}$ & $6.25 \pm 0.63 \mathrm{i}$ & $6.00 \pm 0.50 \mathrm{~g}$ & $21.67 \pm 1.10 \mathrm{~d}$ \\
\hline \multirow[t]{4}{*}{ Nobili } & 0 & $0.16 \pm 0.04 \mathrm{e}$ & $3.20 \pm 0.34 b$ & $1.85 \pm 0.05^{\mathrm{e}}$ & $11.20 \pm 0.27 b$ & $9.00 \pm 0.01 \mathrm{a}$ & $38.72 \pm 2.60 \mathrm{ab}$ \\
\hline & 50 & $0.90 \pm 0.15 \mathrm{a}$ & $3.17 \pm 0.21 b$ & $1.90 \pm 0.08 \mathrm{~d}$ & $10.68 \pm 1.10 \mathrm{c}$ & $9.00 \pm 0.01 \mathrm{a}$ & $36.33 \pm 1.60 \mathrm{~b}$ \\
\hline & 100 & $0.83 \pm 0.25 b$ & $3.10 \pm 0.18 c$ & $1.98 \pm 0.09 \mathrm{c}$ & $9.90 \pm 0.90 \mathrm{~d}$ & $8.25 \pm 0.01 c$ & $35.14 \pm 1.01 \mathrm{bc}$ \\
\hline & 200 & $0.50 \pm 0.10 \mathrm{~d}$ & $3.08 \pm 0.19 \mathrm{c}$ & $1.95 \pm 0.10 \mathrm{c}$ & $9.00 \pm 0.50 \mathrm{e}$ & $7.25 \pm 0.50 \mathrm{e}$ & $20.55 \pm 1.20 \mathrm{~d}$ \\
\hline
\end{tabular}

Cultivar $(\mathrm{C})$

Salt treatment $(S)$

Interaction C X S

NS

NS

NS

Values shown are means $(\mathrm{n}=10) \pm \mathrm{SD}$; within columns, means followed by different letter are significantly different $(\mathrm{p}<0.05)$.

${ }^{* *},{ }^{*}$ significant at 1 and $5 \%$ probability levels, respectively, NS not significant 
486

Table 2. Effect of salt stress on ions concentrations $\left(\mathrm{g} \mathrm{kg}^{-1}\right)$ in pepper cultivars at vegetative stage (42 DAP)

\begin{tabular}{|c|c|c|c|c|c|c|c|}
\hline Cultivar & & $\begin{array}{l}\text { Treatment } \\
(\mathrm{mM} \mathrm{NaCl})\end{array}$ & $\mathrm{Na}$ & K & $\mathrm{Ca}$ & $\mathrm{Mg}$ & $\mathrm{K} / \mathrm{Na}$ \\
\hline \multirow{12}{*}{ Granada } & \multirow{4}{*}{ Leaf } & 0 & $2.90 \pm 0.02 \mathrm{~g}$ & $38.00 \pm 0.82 \mathrm{a}$ & $41.00 \pm 0.82 \mathrm{a}$ & $38.50 \pm 0.18 \mathrm{a}$ & $13.10 \mathrm{c}$ \\
\hline & & 50 & $5.60 \pm 0.03 f$ & $28.60 \pm 0.18 \mathrm{c}$ & $36.00 \pm 0.82 \mathrm{~b}$ & $29.00 \pm 1.82 \mathrm{~b}$ & $5.10 \mathrm{e}$ \\
\hline & & 100 & $8.60 \pm 0.07 d$ & $25.00 \pm 0.82 \mathrm{~d}$ & $28.00 \pm 0.82 \mathrm{c}$ & $21.60 \pm 0.18 \mathrm{c}$ & $2.90 \mathrm{f}$ \\
\hline & & 200 & $18.00 \pm 0.82 \mathrm{a}$ & $23.50 \pm 0.18 \mathrm{~d}$ & $20.60 \pm 0.18 \mathrm{~d}$ & $19.40 \pm 0.23 \mathrm{~cd}$ & $1.30 \mathrm{f}$ \\
\hline & \multirow{4}{*}{ Stem } & 0 & $2.10 \pm 0.08 \mathrm{~g}$ & $34.60 \pm 0.18 b$ & $29.00 \pm 0.82 \mathrm{c}$ & $20.00 \pm 1.82 \mathrm{c}$ & $16.48 \mathrm{~b}$ \\
\hline & & 50 & $5.20 \pm 0.07 \mathrm{f}$ & $31.50 \pm 0.18 \mathrm{bc}$ & $18.00 \pm 0.58 \mathrm{de}$ & $15.90 \pm 0.52 \mathrm{~d}$ & $6.06 \mathrm{e}$ \\
\hline & & 100 & $10.20 \pm 0.27 \mathrm{~cd}$ & $27.90 \pm 0.50 \mathrm{~d}$ & $9.60 \pm 0.18 \mathrm{~g}$ & $10.60 \pm 0.18 \mathrm{e}$ & $2.74 \mathrm{f}$ \\
\hline & & 200 & $14.40 \pm 0.23 b$ & $19.90 \pm 0.75 \mathrm{de}$ & $8.00 \pm 0.02 \mathrm{~g}$ & $8.70 \pm 0.08 \mathrm{e}$ & $1.38 \mathrm{f}$ \\
\hline & \multirow{4}{*}{ Root } & 0 & $1.80 \pm 0.06 \mathrm{~d}$ & $21.80 \pm 0.18 \mathrm{~d}$ & $23.90 \pm 0.52 \mathrm{~d}$ & $38.90 \pm 0.18 \mathrm{a}$ & $12.11 \mathrm{~cd}$ \\
\hline & & 50 & $5.40 \pm 0.06 f$ & $16.90 \pm 0.52 \mathrm{e}$ & $18.00 \pm 082 \mathrm{de}$ & $29.80 \pm 0.38 \mathrm{~b}$ & $3.13 \mathrm{f}$ \\
\hline & & 100 & $10.60 \pm 0.25 \mathrm{~cd}$ & $12.70 \pm 0.18 \mathrm{f}$ & $13.40 \pm 0.83 \mathrm{e}$ & $25.90 \pm 0.52 \mathrm{c}$ & $1.20 \mathrm{f}$ \\
\hline & & 200 & $12.80 \pm 0.18 \mathrm{c}$ & $9.50 \pm 0.18 \mathrm{fg}$ & $15.60 \pm 0.18 \mathrm{e}$ & $20.50 \pm 0.18 \mathrm{c}$ & $0.74 \mathrm{~g}$ \\
\hline \multirow{12}{*}{ Goliath } & \multirow{5}{*}{ Leaf } & 0 & $1.60 \pm 0.08 \mathrm{~d}$ & $29.90 \pm 0.52 \mathrm{c}$ & $34.00 \pm 0.82 \mathrm{~b}$ & $31.50 \pm 0.18 \mathrm{~b}$ & $18.70 \mathrm{~b}$ \\
\hline & & 50 & $4.40 \pm 0.08 f$ & $18.50 \pm 0.18 \mathrm{de}$ & $29.00 \pm 0.82 \mathrm{c}$ & $27.00 \pm 0.58 \mathrm{bc}$ & $4.20 \mathrm{e}$ \\
\hline & & 100 & $7.70 \pm 0.03 e$ & $14.40 \pm 0.18 \mathrm{f}$ & $26.00 \pm 0.82 \mathrm{~cd}$ & $19.50 \pm 0.18 \mathrm{~cd}$ & $1.90 \mathrm{f}$ \\
\hline & & 200 & $14.60 \pm 0.18 b$ & $11.50 \pm 0.18 \mathrm{f}$ & $15.60 \pm 0.18 \mathrm{e}$ & $13.50 \pm 0.18 \mathrm{~d}$ & $0.80 \mathrm{~g}$ \\
\hline & & 0 & $2.20 \pm 0.04 \mathrm{~g}$ & $22.00 \pm 3.36 \mathrm{~d}$ & $25.30 \pm 0.18 \mathrm{~cd}$ & $24.40 \pm 0.18 \mathrm{bc}$ & $10.00 \mathrm{~d}$ \\
\hline & \multirow{3}{*}{ Stem } & 50 & $4.90 \pm 0.09 \mathrm{f}$ & $16.80 \pm 0.18 \mathrm{e}$ & $19.00 \pm 0.82 \mathrm{de}$ & $13.00 \pm 0.58 \mathrm{~d}$ & $3.43 \mathrm{f}$ \\
\hline & & 100 & $7.60 \pm 0.08 \mathrm{e}$ & $11.30 \pm 0.18 \mathrm{f}$ & $10.90 \pm 0.52 \mathrm{~g}$ & $9.20 \pm 0.27 \mathrm{e}$ & $1.49 \mathrm{f}$ \\
\hline & & 200 & $12.70 \pm 0.18 \mathrm{c}$ & $9.20 \pm 0.27 \mathrm{fg}$ & $6.40 \pm 0.08 \mathrm{~g}$ & $7.00 \pm 0.02 \mathrm{e}$ & $0.72 \mathrm{~g}$ \\
\hline & \multirow{4}{*}{ Root } & 0 & $1.50 \pm 0.01 \mathrm{~d}$ & $16.00 \pm 0.82 \mathrm{e}$ & $18.00 \pm 0.82$ & $28.90 \pm 0.52 b$ & $10.66 \mathrm{~d}$ \\
\hline & & 50 & $4.80 \pm 0.08 \mathrm{f}$ & $10.60 \pm 0.18 \mathrm{f}$ & $16.09 \pm 0.52 \mathrm{e}$ & $23.00 \pm 2.94 \mathrm{c}$ & $2.21 \mathrm{f}$ \\
\hline & & 100 & $8.80 \pm 0.08 \mathrm{~d}$ & $8.60 \pm 0.08 \mathrm{fgh}$ & $11.40 \pm 0.18 \mathrm{~g}$ & $15.40 \pm 0.23 \mathrm{~d}$ & $0.98 \mathrm{f}$ \\
\hline & & 200 & $9.70 \pm 0.58 \mathrm{~d}$ & $6.20 \pm 0.08 \mathrm{~h}$ & $8.00 \pm 0.02 \mathrm{~g}$ & $11.00 \pm 0.82 \mathrm{de}$ & $0.64 \mathrm{~g}$ \\
\hline \multirow{12}{*}{ Nobili } & \multirow{5}{*}{ Leaf } & 0 & $1.50 \pm 0.08 \mathrm{~g}$ & $34.40 \pm 0.18 b$ & $43.00 \pm 0.82 \mathrm{a}$ & $35.40 \pm 0,23 \mathrm{a}$ & $22.93 \mathrm{a}$ \\
\hline & & 50 & $6.50 \pm 0.08 \mathrm{ef}$ & $25.00 \pm 0.18 \mathrm{~d}$ & $34.90 \pm 0.52 b$ & $29.00 \pm 0.82 b$ & $3.85 \mathrm{f}$ \\
\hline & & 100 & $9.90 \pm 0.29 \mathrm{~d}$ & $22.90 \pm 0.52 \mathrm{~d}$ & $20.00 \pm 0.82 \mathrm{~d}$ & $19.60 \pm 0.18 \mathrm{c}$ & $2.31 \mathrm{f}$ \\
\hline & & 200 & $16.40 \pm 0.36 \mathrm{a}$ & $21.00 \pm 0.36 \mathrm{~d}$ & $22.40 \pm 0.18 \mathrm{~d}$ & $14.60 \pm 0.18 \mathrm{~d}$ & $1.28 \mathrm{f}$ \\
\hline & & 0 & $2.20 \pm 0.08 \mathrm{~g}$ & $30.90 \pm 0.52 b c$ & $28.90 \pm 0.52 \mathrm{c}$ & $23.00 \pm 0.94 \mathrm{c}$ & $14.05 \mathrm{c}$ \\
\hline & \multirow{3}{*}{ Stem } & 50 & $4.40 \pm 0.06 f$ & $29.00 \pm 0.82 \mathrm{c}$ & $18.40 \pm 0.18 \mathrm{de}$ & $14.50 \pm 0.18 \mathrm{~d}$ & $6.59 \mathrm{e}$ \\
\hline & & 100 & $9.90 \pm 0.19 \mathrm{~d}$ & $22.00 \pm 0.36 \mathrm{~d}$ & $12.80 \pm 0.18 \mathrm{f}$ & $11.00 \pm 0.82 \mathrm{de}$ & $2.2 \mathrm{f}$ \\
\hline & & 200 & $14.80 \pm 0.18 \mathrm{~b}$ & $14.00 \pm 0.82 \mathrm{f}$ & $9.90 \pm 0.52 \mathrm{~g}$ & $10.40 \pm 0.18 \mathrm{e}$ & $0.95 \mathrm{~g}$ \\
\hline & \multirow{4}{*}{ Root } & 0 & $1.70 \pm 0.08 \mathrm{~g}$ & $19.00 \pm 0.82 \mathrm{de}$ & $21.00 \pm 4.16 \mathrm{~d}$ & $30.70 \pm 0.18 b$ & $11.18 \mathrm{~cd}$ \\
\hline & & 50 & $4.70 \pm 0.08 \mathrm{f}$ & $13.90 \pm 0.52 \mathrm{f}$ & $19.40 \pm 0.18 \mathrm{de}$ & $26.60 \pm 0.18 \mathrm{bc}$ & $2.96 \mathrm{f}$ \\
\hline & & 100 & $9.40 \pm 0.36 \mathrm{~d}$ & $6.60 \pm 0.08 \mathrm{~h}$ & $14.00 \pm 1.82 \mathrm{f}$ & $18.00 \pm 0.82 \mathrm{~cd}$ & $0.70 \mathrm{~g}$ \\
\hline & & 200 & $10.40 \pm 0.36 b$ & $8.00 \pm 0.08$ fgh & $10.60 \pm 0.18 \mathrm{~g}$ & $12.00 \pm 0.02 \mathrm{de}$ & $0.77 \mathrm{~g}$ \\
\hline \multicolumn{8}{|c|}{ wo way ANOVA results } \\
\hline Cultivars (C) & & & $*$ & * & $*$ & NS & * \\
\hline Salt treatment $(S)$ & & & ** & * & * & $*$ & * \\
\hline Interaction $\mathrm{C} x \mathrm{~S}$ & & & * & * & NS & NS & * \\
\hline
\end{tabular}

Values shown are means $(\mathrm{n}=5) \pm \mathrm{SD}$; within columns, means followed by different letter are significantly different $(\mathrm{p}<0.05)$.

**, ${ }^{*}$ significant at 1 and $5 \%$ probability levels, respectively, NS not significant

enzyme activity (Sivtsev, 1973). In salt tolerant 'Granada' salt affected leafCHL content at high salt level $(200 \mathrm{mM})$ (Fig. 1.). $\mathrm{CHL}$ degrades depending on the degree of salt levels in the soil solution, especially in extreme salt stress $\left(10 \mathrm{dS} \mathrm{m}^{-1}\right)$ (Giri et al., 2003), causing to reduce net photosynthetic rate, especially in extreme salt stress (Takemura et al., 2000). Similar results were reported by Turan et al. (2007) with lentil plants.

\section{Leaf relative water content}

Leaf RWC of pepper cultivars at different salinity levels is depicted in Fig. 2. There are significant differences between cultivars. The increased RWC values in salt-tolerant cultivars 'Granada' and 'Nobili' under $100 \mathrm{mM} \mathrm{NaCl}$ than salt-sensitive 'Goliath' suggest that, accumulation of osmolytes such as SS,

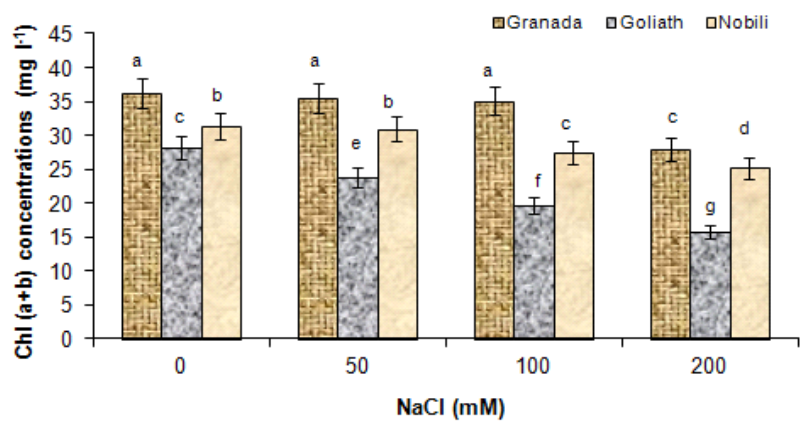

Fig. 1. Effect of salt stress on chlorophyll concentrations in pepper varieties at vegetative stage (42 DAP). Bars are means $(n=5)$ \pm SD. Means followed by different letter are significantly different $(\mathrm{p}<0.05)$ 
PRO, SP, FAA (Fig. 3) makes the surplus of water uptake possible. Similar results were obtained by Salwa et al. (2010) with peanut cultivars. On the contrary, a significant decrease in RWC was found at high salinity level $(200 \mathrm{mM})$ in all cultivars. These results may be attributed to the accumulation of toxic ions such as $\mathrm{Na}^{+}$and $\mathrm{Cl}$, reducing leaf expansion and stomata closure leading to a reduction in intracellular $\mathrm{CO}_{2}$ partial pressure (Hasegawa et al., 2000). According to Munns (2002) studies, salinity reduces the ability of plants to take up water, and this quickly causes reductions in growth rate, along a suite of metabolic changes identical to those causes by water stress.

\section{Osmolyte contents}

The presence of $\mathrm{NaCl}$ resulted in a significant increase in SS, SP, PRO and FAA contents in leaves of all cultivars compared to untreated plants, thereby playing a major role as osmotic adjustment (Fig. 3A, B, C and D). The salt tolerant 'Granada' accumulated the highest amount of all osmolytes followed by the moderately tolerant 'Nobili' and the saltsensitive 'Goliath'. Compartmentation of ions in vacuoles and accumulation of compatible solutes in the cytoplasm are commonly proposing mechanisms to salt tolerance of plants (Munns, 2002). The plants supplied with $\mathrm{NaCl}$ showed significantly higher increase and accumulation of SS concentrations in leaves of 'Granada' compared to all other cultivars (Fig. 3A). When abiotic stress affects plant functionality, alterations in photosynthesis and carbon partitioning are common features that take place at organ level as well as in whole plant (Gill et al., 2003). SS do not only function as metabolic resources and structural constituents of cells, they also act as signals regulating various processes associated with plant growth and development (Jang and Sheen, 1997). Recent studies for increasing tolerance to environmental stresses, through metabolic engineering of compatible solutes, have shown that increases in SS and/or other osmolytes provide optimism to increase plant tolerance to abiotic stresses such as drought, salinity and cold (Cusido $e t$ al., 1987; Rathinasabapathi, 2000). SP content in plants increased significantly under salt stress in all cultivars compared to untreated plants (Fig. 3B). In salt tolerant species, the osmotic balance of the cytoplasm is ensured by an active synthesis of the organic compounds (Grigore et al., 2011). In plants, SP are involved in osmotic adjustment (Nouck et al., 2016). They are stored as nitrogen under salt-stress and re-used when the stress is removed (Singh et al., 1987). PRO content in plants increased significantly under salt stress in all cultivars compared to untreated plants (Fig. 3C). PRO has been widely considered to be a compatible solute that accumulates in plant in response of wide variety of environmental stresses and confers stress tolerance by contributing to osmotic adjustment, protecting proteins, membranes and quenching reactive oxygen species (Mudgal et al., 2010). Similar findings were reported by Ashraf and Foolad (2007); Grigore et al. (2011); Meguekam et al. (2014) and Theerawitaya et al. (2015). According to Kant et al. (2006), halophytes accumulate more PRO than glycophytes, and it has been related to the suppression of PRO catabolism by proline oxidizing enzyme (proline dehydrogenase), and enhanced synthesis of PRO via pyrroline-5-carboxylate synthetase. PRO is significantly accumulated under salt stress and performs the positive role in the adaptation of cells to salt and water stress (Kaviani, 2008).
In this study, application of $\mathrm{NaCl}$ had a positive effect on leaf FAA content with the highest increase found in 'Granada' and the lowest in 'Goliath'(Fig. 3D). According to Cusido et al. (1987) the deficit of $\mathrm{K}$ induced by salinity increased the levels of FAA, especially of aspartic acid, glutamic acid and PRO.

\section{Antioxidant compounds}

In response to stress, plants activate powerful antioxidant systems, both enzymatic (e.g., SOD, POD, catalase, glutathione reductase) and non-enzymatic (FLA, TP, carotenoids, vitamins C and E) (Ashraf, 2009; Kahrizi et al., 2012). In the present study, $\mathrm{NaCl}$ addition led to a significant increase in SOD, POD, TP contents in all cultivars, on the contrary, decreased in FLA content (Fig. 4). Similarly, Azooz et al. (2009) showed a positive antioxidant response to salt stress on various crop (eg. Zea mays and Lycopersicum esculentum, respectively). The inhibition effect of salt stress on FLA content in all cultivars is due to the reduction of functions which are the primary significance in plants suffering from severe stress conditions (Brunetti et al., 2013). According to Agati et al. (2012), FLA is located in the nucleus of mesophyll cells, and hence capable of quenching $\mathrm{H}_{2} \mathrm{O}_{2}$ and $\mathrm{H}_{2} \mathrm{O}_{2}$-generated hydroxyl radical. In this study, the highest increase in SOD, POD and TP activities was

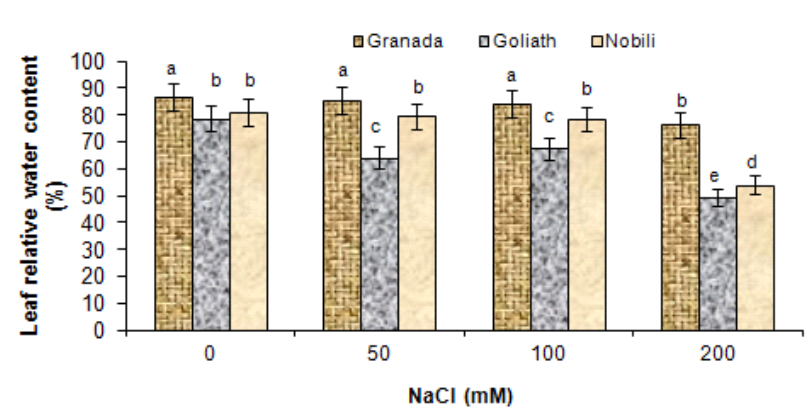

Fig. 2. Effect of salt on leaf relative water content in pepper varieties at vegetative stage (42 DAP). Bars are means $(n=5) \pm S D$. Means followed by different letter are significantly different $(\mathrm{p}<0.05)$
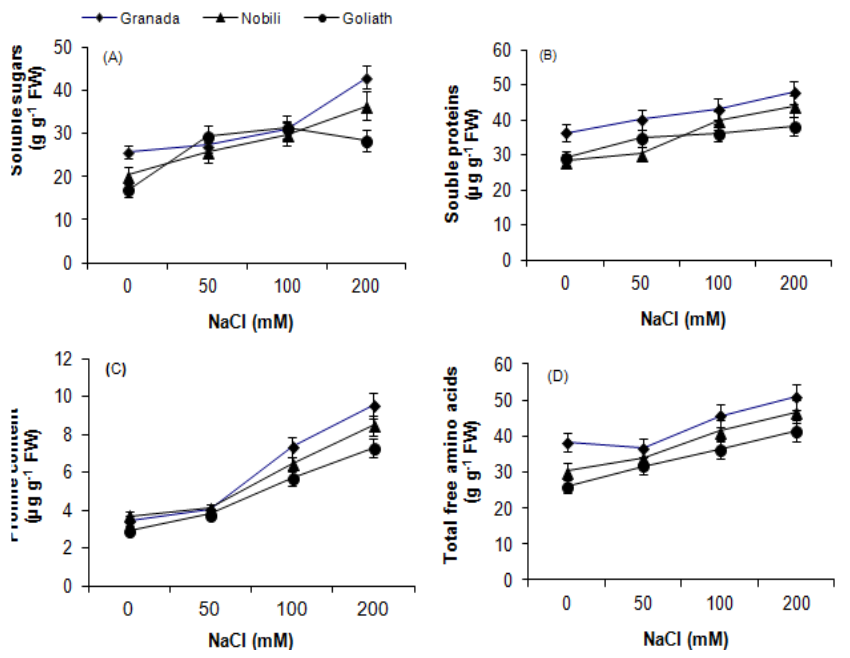

Fig. 3. Effect of salt on accumulation of osmolytes in pepper cultivars (42 DAP). Soluble carbohydrates (A), soluble proteins $(\mathrm{B})$, proline content $(\mathrm{C})$ and total free amino acids (D). Bars are means $(n=5) \pm S D$ 
488

found in salt-tolerant 'Granada' and the lowest in salt-sensitive 'Goliath' (Fig. 4B, C and D). Similarly, the level of antioxidant enzymes was higher in salt-tolerant than in salt-sensitive species under various environmental stresses (Demiral and Turkan, 2005). To cope with oxidative damage under extremely adverse conditions like salt stress, plant have developed an antioxidant defense system that includes the antioxidant enzymes SOD, POD and catalase (Karanlik, 2001; Foyer and Noctor, 2005). SOD detoxifies superoxide anion free radicals accompanying the formation of $\mathrm{H}_{2} \mathrm{O}_{2}$ which is very damaging to the chloroplasts, nucleic acids and proteins (Marschner, 1995). Numerous studies have reported that $\mathrm{NaCl}$ treatment increased SOD activity (Ahmad et al. 2008; Gama et al., 2008; Maia et al., 2010; Chookhampaeng, 2011; Kahrizi et al., 2012). Accordingly, we also found higher activity of POD in leaves of all the cultivars under salt stress conditions (Fig. 4D). Numerous studies have reported that salinity treatment increased POD activity in plants (Jebara et al., 2005; Mohamed and Aly, 2008; Chookhampaeng, 2011; Sevengor et al., 2011). An increase in the antioxidative enzymes under salt stress could be indicative of an increased production of ROS and build up of a protective mechanism to reduce oxidative damage triggered by stress in plants. POD in cytosol and chloroplast can perfectly scavenge $\mathrm{H}_{2} \mathrm{O}_{2}$ (Kahrizi et al., 2012).
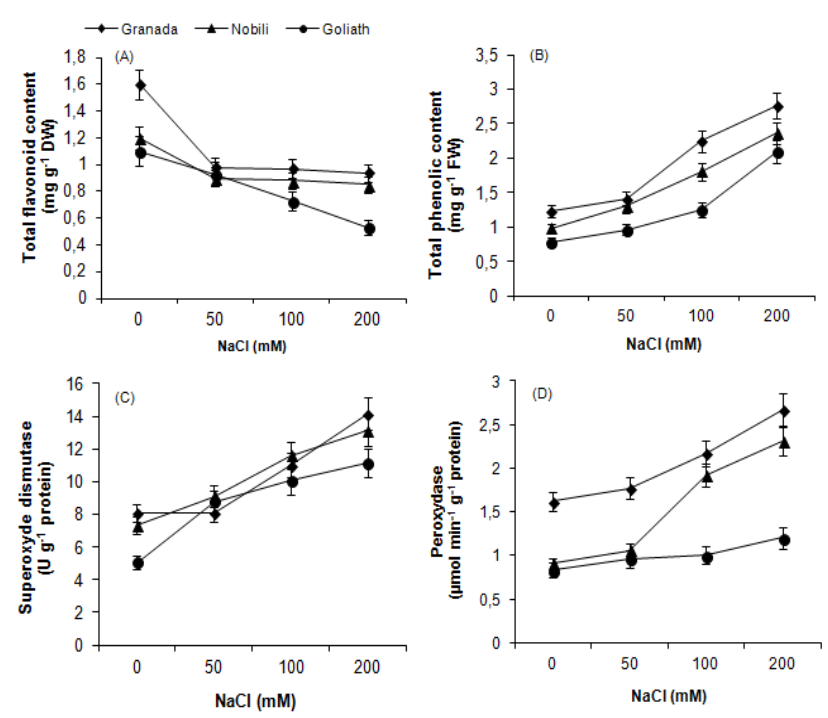

Fig. 4. Effect of salt on antioxidant compounds in pepper cultivars at the vegetative stage (42 DAP). Total flavonoid content $(\mathrm{A})$, total phenolic content $(\mathrm{B})$, superoxide dismutase $(C)$ and peroxidase activities $(D)$. Bars are means $(n=5) \pm S D$

\section{Conclusions}

The pepper cultivars in this study showed differential responses for growth, osmolytes accumulation and enzymes activities measured under salt stress. The scavenging system in salt-tolerant cultivar, 'Granada' exhibited higher TP content, POD and SOD activity, than in the salt-sensitive cultivar 'Goliath'. Thus, the salt tolerance of these pepper cultivars seems to be linked to the activities of these antioxidant enzymes. The salt tolerance of pepper cultivars could induce antioxidative enzyme system more efficiently, resulting in higher osmolytes accumulation under salt stress. The conducted study confirmed the genetic variability in salt tolerance among three pepper cultivars which are widely used in Cameroon. 'Granada', followed by 'Nobili', intermediate ones, was found to be the most tolerant cultivar based on the majority of growth parameters, osmolytes accumulation and enzymes activities measured. On the contrary, the most salt sensitive one was 'Goliath', as it presented their greatest salt effect plant growth inhibition at low salinity level $(50 \mathrm{mM})$, low osmolytes accumulation and low enzymes activities assessed. The SS, SP, PRO and FAA were enriched in cellular levels of leaf tissues to play a key role in osmoregulation of salt defense mechanism to protect salt-tolerant 'Granada' from saltinduced toxicity and thus it could be an excellent cultivar to grow in salt-affected soils. FLA content, K, Ca and Mg concentrations were significantly reduced with increasing salinity in all cultivars. The highest $\mathrm{Na}$ concentrations under $200 \mathrm{mM} \mathrm{NaCl}$ were detected in the roots and the lowest ones in the leaves of the salt-sensitive 'Goliath'.

\section{Acknowledgements}

The authors thank Dr. ADAMOU and Dr. FOKOM of the Biotechnology Center of Nkolbisson for their excellent technical assistance.

\section{References}

Abbaspour $\mathrm{H}$ (2012). Effects of salt stress on lipid peroxidation, antioxidative enzymes and proline accumulation in pistachio plants. Journal of Medicinal Plant Research 6(3):526-529.

Abogadallah GM, SeragM, Quick WP(2010). Fine and coarse regulation of reactive oxygen species in the salt tolerant mutants of barnyard grass and their wild type parents under salt stress. Physiologia Plantarum 138:6073.

Agati G, Azzarello E, Pollastri S, Tattini M (2012). Flavonoids as antioxidants in plants: Location and functional significance. Plant Science 196:67-76.

Ahmad P, John R, Sarwat M, Umar S (2008). Response of proline, lipid peroxidation and antioxidative enzymes in two varieties of Pisum sativum L. under salt stress. International Journal of Plant Production 2:353-365.

Al-Karaki GN (2000). Growth, water use efficiency, and sodium and potassium acquisition by tomato cultivars grown under salt stress. Journal of Plant Nutrition 23:1-8.

Arnon DI (1949). Copper enzymes in isolated chloroplasts. Polyphenylodase in Beta vulgaris. Plant Physiology 24:1-15.

Ashraf MY, Foolad MR (2007). Roles of gycine betaine and proline in improving plant abiotic stress resistance. Environmental and Experimental Botany 59:206-216.

Ashraf M (2009). Biotechnological approach of improving plant salt tolerance using antioxidants as markers. Biotechnology Advances 27:84 93.

Azooz MM, Ismail AM, Abou-Elhamd MF (2009). Growth, lipid peroxidation and antioxidant enzyme activities as a selection criterion for the salt tolerance of three maize cultivars grown under salinity stress. International Journal of Agriculture and Biology 11:21-26.

Bates LS, Waldren RP, Teara ID (1973). Rapid determination of free 
proline for water stress studies. Plant and Soil 39:205-207.

Bayuelo-Jiménes JS, Debouck DG, Lynch JP (2002). Salinity tolerance of Phaseolus species during early vegetative growth. Crop Science 42:2184 2192

Bergmann H, Leinhos V, Machelet B (1994). Increase of stress resistance in crop plants by using phenolic compounds. Acta Horticulturae 381:390397.

Bradford MM (1976). A rapid and sensitive method for the quantitation of microgram quantities of proteins utilizing the principle of protein-dye binding. Analytical Biochemistry 72:248-254.

Bray EA, Bailey-Serres, Weretilnyk E (2000). Responses to abiotic stress. In: Buchanan B, Gruissem W, Jones R (Eds.). Biochemistry and molecular biology of plants. American Society of Plant Physiology, Rockville pp1158-1203.

Brunetti C, Ferdinando MD, Fini A, Pollastri S, Tattini M (2013). Flavonoids as antioxidants and developmental regulators: relative significance in plants and humans. International Journal of Molecular Sciences 14:3540-3555.

Chang CC, Yang MH, Wen HM, Chern JC (2002). Estimation of total flavonoid content in propolis by two complementary colorimetric methods. Journal of Food Drug Analysis 10(3):178-182.

Chookhampaeng S (2011). The effect of salt stress on growth, chlorophyll content, proline content and antioxidative enzymes of pepper (Capsicum annuun L.) seedling. European Journal of Scientific Research 49:103-109.

Cody V, Middleton E, HarborneJB (1985). Plant Flavonoids in Biology and Medicine. Biochemical, pharmacological, and structure-activity relationships. New York, 21-22 July, 1985. Proceedings pp15-24.

Cordovilla MD, Ligero F, Lluch C (1999). Effect of salinity on growth, nodulation and nitrogen assimilation in nodules of faba bean (Vicia faba L.). Applied Soil Ecology 1:1-7.

Cusido RM, Palazon G, Altabella T, Morales C (1987). Effect of salinity of soluble protein, free aminoacids and nicotine contents in Nicotiana rustica L. Plant and soil 102(1):55-60.

Demiral T, Turkan I (2005). Comparative lipid peroxidation, antioxidant systems and proline content in roots of two rice cultivars differing in salt tolerance. Environmental and Experimental Botany 53:247-257.

Dhindsa RS, Plumb-Dhindsa P, Thorne TA (1981). Leaf Senescence: Correlated with increased levels of membrane permeability and lipid peroxidation and decreased level of superoxide dismutase. Journal of Experimental Botany 32:93-101.

Dubois M, Gilles KA, Hamilton JK, Rebers PA, Smith F (1956). Colorimetric method for determination of sugars and related substances. Analytical Chemistry 28:350-356.

Flowers TJ, Colmer TD (2008). Salinity tolerance in halophytes. New Phytologist 179(4):945-963.

Foyer $\mathrm{CH}$, Noctor $\mathrm{G}$ (2005). Oxidant and antioxidant signaling in plants: a re-evaluation of the concept of oxidative stress in a physiological context. Plant, Cell andEnvironment 28:1056-1071.

Gama PBS, Tanaka K, Eneji AE, Eltayeb AE, Siddig KE (2008). Saltinduced stress effect on biomass, photosynthetic rate and reactive oxygen species scavenging enzyme accumulation in common bean. Journal of Plant Nutrition 32:837-854.
Giri B, Kapoor R, Mukerji KG (2003). Influence of arbuscular mycorrhizal fungi and salinity on growth, biomass, and mineral nutrition of Acacia auriculiformis. Biology and Fertility of Soils 38:170-175.

Gill PK, Sharma AD, Singh P, Bhullar SS (2003). Changes in germination, growth and soluble sugar contents of Sorghum bicolor (L.) Moench seeds undervarious abiotic tresses. Plant Growth Regulation 40:157-62.

Grigore MN, Boscaiu M, Vicente O (2011). Assessment of the relevance of osmolyte biosynthesis for salt tolerance of halophytes under natural conditions. The European Journal of Plant Science and Biotechnology 5:12-19.

Hasegawa PM, Bressan RA, Zhu JK, Bohnert HJ (2000). Plant cellular and molecular responses to high salinity. Annual Review of Plant Physiology and Plant Molecular Biology 51:463-499.

Hoagland DR, Arnon DI (1950). The water culture method for growing plants without soil. University of California, College of Agriculture, Agricultural Experiment Station, Baltimore, USA.

Hosseini G, Thengane RJ (2007). Salinity tolerance in cotton (Gossypium hirsutum L) genotypes. International Journal of Botany 3(1):48-55.

Howard LR, Talcott ST, Brenes CS, Villalon B (2000). Changes in phytochemical and antioxidant activity of selected pepper cultivars (Capsicum spp.) as influenced by maturity. Journal of Agricultural and Food Chemistry 48:1713-1720.

Iqbal Q, Amjad M, Asi MR, Arino A (2013). Characterization of capsaicinoids and antioxidant in hot pepper as influenced by hybrid and harvesting stage. Plant Foods for Human Nutrition 68(4):358-63.

Jang JC, Sheen J (1997). Sugar sensing in higher plants. The Plant Cell 9:519.

Jebara C, Jebara M, Limam F, Aouani ME (2005). Changes in ascorbate peroxidase, catalase, guaiacol peroxidase and superoxide dismutase activities in common bean (Phaseolus vulgaris) nodules under salt stress. Journal of Plant Physiology 162:929-936.

Joseph B, Jini D (2011). Development of salt stress-tolerant plants by gene manipulation of antioxidant enzymes. Asian Journal of Agricultural Research 5:17-27.

Kahrizi S, Sedghi M, Sofalian O (2012). Effect of salt stress on proline and activity of antioxidant enzymes in ten durum wheat cultivars. Annals of Biological Research 3:3870-3874.

Kant S, Kant P, Raveh E, Barak S (2006). Evidence that differential gene expression between the halophytes, Thellungiella halophila and Arabidopsis thaliana is responsible for higher levels of the compatible osmolyte proline and tight control of $\mathrm{Na}^{+}$uptake in T. halophila. Plant, Cell and Environment 29(7):1220-1234.

Karanlik S (2001). Resistance to salinity in different wheat genotypes and physiological mechanisms involved in salt resistance. $\mathrm{PhD}$ thesis, Institute of Natural and Applied Science, University of Cukur Ova, Turkey.

Kaviani B (2008). Proline accumulation and growth of Soybean callus under salt and water stress, International Journal of Agriculture and Biology 10:221-223.

KumarN, Krishnamoorty V,Nalina L, Soorianathasundharam K(2002).A new factor for estimating total leaf area in banana. InfoMusa 11:42-43.

Levitt J (1980). Responses of plant to environmental stress. Vol. II: Water, radiation, salt and other stresses. United Kingdom. Edition Academic 
490

Press. London pp395-434.

LiN, Chen S, Zhou X, LiC, ShaoJ, WangR, FritzE, Hüttemannn, Polle A (2008). Effect of $\mathrm{NaCl}$ on photosynthesis, salt accumulation, and compartmentation in two mangrove species, Kandelia candel and Bruguieragymnorrhiza. Aquatic Botany 88:303-310.

Maia JM, De-Macedo CEC, Voigt EL, Freitas JBS, Silveira JAG (2010). Antioxidative enzymatic protection in leaves of two contrasting cowpea cultivars under salinity. Biologia Plantarum 54:159-163.

Malstrom B, Andreasson L, Reinhammer B (1975). The enzymes. In: Boyer $P(E d)$. Academy Press, New York.

Marigo G (1973). On a fractionation method and estimation of the phenolic compounds in plants. Analysis 2:106-110.

Marschner H (1995). Mineral nutrition of higher plants. Academic Press, San Diego.

Meguekam TL, Taffouo VD, Marius-Nicusor G, Maria ZM, Youmbi E, Akoa A (2014). Differential responses of growth, chlorophyll content, lipid peroxidation and accumulation of compatible solutes to salt stress in peanut (Arachis hypogaea L.) cultivars. African Journal of Biotechnology 13:4577-4585.

Mudgal V, Madaan N, Mudgal A (2010). Biochemical mechanisms of salt tolerance in plants: a review. International Journal of Botany 6:136-143.

Mohamed AA, Aly AA (2008). Alternations of some secondary metabolites and enzymes activity by using exogenous antioxidant compound in onion plants grown under seawater salt stress. European Journal of Scientific Research 3:139-146.

Munns R(2002). Comparative physiology of salt and water stress. Plant, Cell and Environment 25:239-250.

Munns R, Tester M (2008). Mechanisms of salinity tolerance. Annual Review of Plant Biology 59:651-681.

Nagesh Babu R, Devaraj VR (2008). High temperature and salt stress response in French bean (Phaseolus vulgaris). Australian Journal ofCrop Science 2:40-48.

Neumann PM (1995). Inhabitation of root growth by salinity stress: Toxicity or an adaptive biophysical response. In: Baluska F, Ciamporova M, Gasparikova O, Barlow PW (Eds). Structure and function of roots. The Netherlands: Kluwer Academic Publishers pp299-304.

Niu X, Bressan RA, Hasegwa PM, Pardo JM (1995). Ion homeostasis in $\mathrm{NaCl}$ stress environments. Plant Physiology 109:735-742.

Nouck AE, Taffouo VD, Tsoata E, Dibong DS, Nguemezi ST, Gouado I, Youmbi E (2016). Growth, biochemical constituents, micronutrient uptake and yield response of six tomato (Lycopersicum esculentum L.) cultivars grown under salinity stress. Journal of Agronomy 15:58-67.

Paridam AK, Das AB (2005). Salt tolerance and salinity effects on plants: a review. Ecotoxicology and Environmental Safety 60:324-349.

Pietta PG (2000). Flavonoids as antioxidants. Journal of Natural Products 63:1035-1042.

Polle A (2001). Dissecting the superoxide dismutase-ascorbate-peroxidaseglutathione-pathway in chloroplasts by metabolic modeling. Computer simulations as a step towards flux analysis. Plant Physiology 126:445462.

Rathinasabapathi B (2000). Metabolic engineering for stress tolerance: installing osmoprotectant synthesis pathways. Annals of Botany 86:70916.
Saghir A, Khan NO, Igbal MZ, Hussain A, Hassan M (2002). Salt tolerance of cotton (Gossypium birsutum L.). Asian Journal of Plant Science 1:715-719.

Salwa AR, Hammad Kh, Shaban A, Manal F, Tantawy (2010). Studies on salinity tolerance of two peanut cultivars in relation to growth, leaf water content. Some chemical aspects and yield. Journal of Applied Sciences Research6(10):1517-1526.

Sevengor S, Yasar F, Kusvuran S, Ellialtioglu S (2011). The effect of salt stress on growth, chlorophyll content, lipid peroxidation and antioxidative enzymes of pumpkin seedling. African Journal of Agricultural Research 6(21):4920-4924.

Singh P, Singh U, Eggum BO, Kumar KA, Andrews DJ (1987). Nutritional evaluation of high protein genotypes of pearl millet (Pennisetum americanum (L.) Leeke). Journal of the Science of Food and Agriculture 38:41-48.

Sivtsev MV, Ponomareva SA, Kuznetsova EA (1973). Effect of salinization and a herbicide on chlorophyllase activity in tomato leaves. Fiziologiya Rastenii 20(1):62-65.

Slama F (1986). Effect of sodium chloride on the growth and mineral nutrition of six crops species. Tropical Agronomy 41(1):21-25.

Strogonov BP, Kabanov VV, Lapina LP, Prykhodko LS (1970). Structure and function of plant cells under salinity conditions. Nauka Publishing House Moscow.

Taffouo VD, Kenne M, Fokam Tasse R, Fotso Wamba O, Fonkou T, Mvondo Z, Amougou A (2004). Differential response of five leguminous species under salt stress. African Agronomy 16(1):33-44.

Taffouo VD, Kouamou JK, Ngalangue LMT, Ndjeudji BAN, Amougou A (2009). Effect of salinity stress on growth, ions partitioning and yield of some cowpea (Vigna unguiculata L walp.) cultivars. International Journal of Botany 5(2):135-145.

Taffouo VD, Wamba FO, Youmbi E, Nono GN, Amougou A (2010). Growth, yield, water status and ionic distribution response of three bambara groundnut (Vigna subterranea L. verdc.) landraces grown under saline conditions. International Journal of Botany 6(1):53-58.

Takemura T, Hanagata N, Suugihara K, Baba S, Karube I, Dubinsky Z (2000). Physiological and biochemical responses to salt stress in the mangrove, Bruguieragymnorrbiza. Aquatic Botany 68:15-28.

Theerawitaya C, Tisarum R, Samphumphuang T, Singh HP, Cha-Um S, Kirdmanee C, Takabe T (2015). Physio-biochemical and morphological characters of halophyte legume shrub, Acacia ampliceps seedlings in response to salt stress under greenhouse. Frontiers in Plant Science 6:630.

Turan MA, Turkmen N, Taban N (2007). Effect of $\mathrm{NaCl}$ on stomacal resistance and proline, chlorophyll, $\mathrm{Na}, \mathrm{Cl}$ and $\mathrm{K}$ concentrations of Lentil plants. Journal of Agronomy 6:378-381.

Waterman PG, Mole S (1994). Analysis of phenolic plant metabolites. Oxford, London, Blackwell Scientific Publications.

Wignarajah K (1992). Growth response of Phaseolus vulgaris to varying salinity regimes. Environmental and Experimental Botany 2:141-147.

Yemm EW, Cocking EC, Ricketts RE (1955). The determination of amino-acids with ninhydrin. Analyst 80:209-214. 